\title{
Occurrence of Hepatozoon spp. in red foxes (Vulpes vulpes) in Romania
}

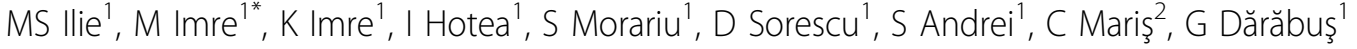 \\ From The 1st Conference on Neglected Vectors and Vector-Borne Diseases (EurNegVec): with Management \\ Committee and Working Group Meetings of the COST Action TD1303 \\ Cluj-Napoca, Romania. 8-11 April 2014
}

Hepatozoon is an apicomplexan parasite of carnivores transmitted by the tick Rhipicephalus sanguineus trough ingestion. Infections in red foxes (Vulpes vulpes) have been recorded in several parts of the world, including European countries, with variable prevalence values.

The study aimed to investigate the occurrence of Hepatozoon spp. in red foxes originating from two counties (Arad and Timiş) of Western Romania.

Fresh/coagulated blood samples from 28 red foxes, killed in sanitary hunting during the routine rabies monitoring, were molecularly analyzed by a conventional PCR using the primers Hep F and Hep R for the presence of Hepatozoon spp.

Overall, 11/28 (39.2\%) investigated samples contained the DNA of the parasite. Most of the positive samples were from Arad County (8/17), while in Timiş County only 3 out of 11 foxes tested were positive.

Occurrence of Hepatozoon canis was reported in Romania in dogs but investigations in wildlife were not performed.

The relatively high prevalence value of the infection recorded in the current survey can be related to the common occurrence of the brown dog tick (Rhipicephalus sanguineus) in the area, documented by previous surveys.

The high prevalence of the parasite among red foxes confirms the presence of sylvatic cycle, highlights the role of wildlife as reservoirs and potential vectors for the infection in the screened region and also the emerging of this pathogen agent in the country.

This is the first report of Hepatozoon spp. infection in red foxes from Romania. The findings support the global changing in vector borne diseases expansion.

\footnotetext{
* Correspondence: mirela.imre@gmail.com

'Department of Parasitology and Parasitic Diseases, Faculty of Veterinary Medicine, BUASVM Timişoara, Romania

Full list of author information is available at the end of the article
}

\section{Funding}

This study was financially supported by CNCS Grant TE_277_116/2010.

\section{Authors' details}

${ }^{1}$ Department of Parasitology and Parasitic Diseases, Faculty of Veterinary Medicine, BUASVM Timişoara, Romania. ${ }^{2}$ Department of Forestry, Faculty of Horticulture and Forestry, BUASVM Timişoara, Romania.

Published: 1 April 2014

doi:10.1186/1756-3305-7-S1-033

Cite this article as: llie et al:: Occurrence of Hepatozoon spp. in red foxes (Vulpes vulpes) in Romania. Parasites \& Vectors 2014 7(Suppl 1):O33.

Submit your next manuscript to BioMed Central and take full advantage of:

- Convenient online submission

- Thorough peer review

- No space constraints or color figure charges

- Immediate publication on acceptance

- Inclusion in PubMed, CAS, Scopus and Google Scholar

- Research which is freely available for redistribution 